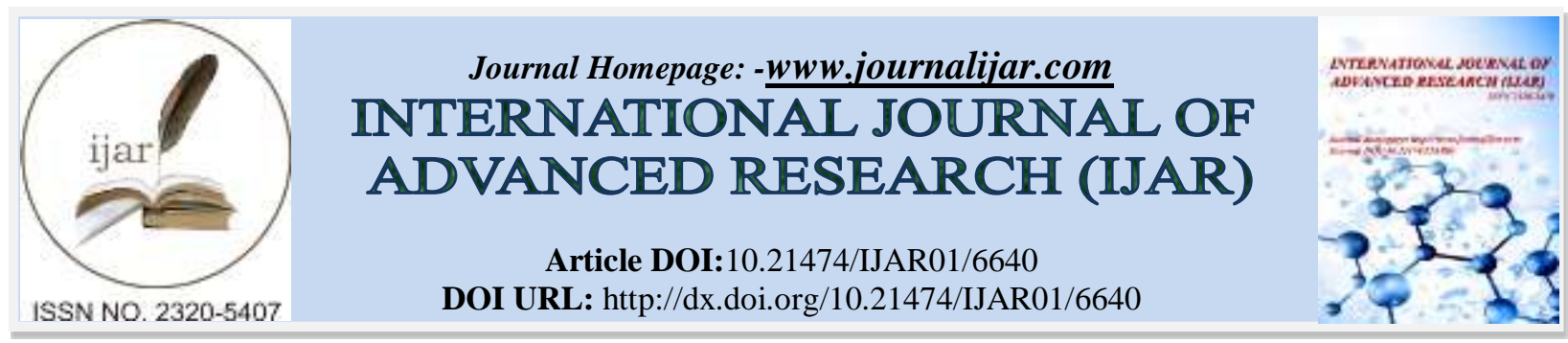

RESEARCH ARTICLE

\title{
ORGANIZATIONAL EFFECTIVENESS: A COMPARATIVE STUDY OF GOVERNMENT AND PRIVATE SECTOR EXECUTIVES.
}

1. Asso. Prof.(DAVPG College Dehradun) .

2. Research Scholar (H.N.B Garhwal Central University, Srinagar).

\section{Manuscript Info}

Manuscript History

Received: 02 January 2018

Final Accepted: 04 February 2018

Published: March 2018

Keywords:-

Organizational Effectiveness.

Government \& Private Sector

Executives.

\begin{abstract}
The present study has tried to explore Perceived organizational Effectiveness among Government and Private Executives. For this data was collected on 200 respondents equally divided into Government $(\mathrm{n}=100, \mathrm{M}=50, \mathrm{~F}=50)$ and Private $(\mathrm{n}=100, \mathrm{M}=50, \mathrm{~F}=50)$ Sector Executives. Dhar \& Dhar's Organizational Effectiveness Scale (2012) was used to measure perceived organizational effectiveness of the respondents. The results of the present study have revealed that 1 . As compared to Government Executive, Private Executives were found to score more on Advancement Opportunity and Task- Significance, 2. Female executives were found to report significantly more on Proactively, Belongings and on Total Organizational Effectiveness as compared to their male counterparts.
\end{abstract}

Copy Right, IJAR, 2018,. All rights reserved.

\section{Introduction:-}

Organizational Effectiveness is the concept of how effective an organization is in achieving its goals. Every employee in a company contributes to organizational effectiveness. Taking into account skills, experience, motivation and rank, some employees play a bigger role than others. Employees of an organization contribute to the development of organization mainly with their knowledge. Organizational effectiveness captures organizational performance plus the myriad internal performance outcomes normally associated with more efficient/effective operations and other external measures that relate to considerations that are broader than those simply associated with economic valuation, such as corporate social responsibilities (Richard, et al, 2009). By definition, Organizational Effectiveness is the efficiency an organization, group or company can meet its goal. How an organization produces its set quota of products, how much waste it produces, or how efficient its processes fall under organizational effectiveness. (Six Sigma, 2017). Organizational Effectiveness has its own six step processes: 1. Leadership, 2. Communication, 3. Accountability, 4. Delivery, 5. Performance and 6. Measurement. Since Organizational Effectiveness is influenced by internal and external factors of organizations, it becomes vital to study the effect of work environment upon Organizational Effectiveness. The present study has tried to compare the Organizational Effectiveness of Private and Government sector executives because the work environment and the intrinsic and extrinsic factors provided by these two sectors to their employees which significantly contribute to rate of production, job motivation, job- involvement and perception of organizational effectiveness, are entirely different. There exists a great difference between the schemas of employees of both the sector. The job in the Government sector is fixed and permanent. Therefore, there is no chance of losing the job. So, they have more job security and their salary and perks are fixed irrespective of their output while this is not so in Private sector. The employees of 
private sector have lesser job- security and they have to prove their worth each and every day. So, it would be interesting to compare the organizational effectiveness of employees working in different sectors.

\section{Method:-}

Objectives:-

1. To identify gender differences on the perception of Organizational- Effectiveness.

2. To identify differences on the perception of Organizational- Effectiveness among Government and Private Sector Executives.

\section{Hypotheses:-}

1. There will be significant gender difference on the perception of all the dimensions of OrganizationalEffectiveness.

2. Executives of Government and Private Sector will differ significantly on the perception of all the dimensions of Organizational- Effectiveness.

\section{Tools:-}

Dhar\&Dhar's Occupational- Effectiveness Scale (2012) was utilized to measure the perception of OrganizationalEffectiveness of the employees. The scale has seven dimensions: 1. Communication, 2. Advancement- opportunity, 3.Proactivity, 4. Belongings, 5. Task- significance, 6. Goal-Orientation and 7. Security.

\section{Sample:-}

The sample of the present study consists of 100 executives equally divided into Government ( $n=50, F=25 \& \mathrm{M}=25$ ) and Private $(n=50, F=25 \& M=25)$ sector executives. The Mean age of the Males was 39.6 years and for Females it was 36.5 years.

\section{Design:-}

The design which is used to conceptualize the study and analyze the data is $2 \times 2$ factorial design with the two classificatory variables being Type of Jobs (Government and Private) and Gender (Males and Females) of the respondents.

\section{Procedure:-}

The sample was selected using purposive sampling method. Respondents were contacted at a pre appointed time and data was collected through questionnaire. It approximately required 20 minutes to complete.

\section{Data-Analysis:-}

The data were analyzed using Mean, SD and ANOVAs.

\section{Results and Analysis:-}

Keeping in view the objectives of the present study, the obtained data was analyzed and the description of the obtained data is as under:

\section{Gender- differences on perception of Organizational effectiveness:-}

As it is clear from the inspection of Table-2 that significant gender differences were found on few dimensions of Organizational effectiveness: they are Proactivity and Belongings. As it is clear from the observation of Table-1 that female executives were found to perceive significantly more Proactivity and Belongings on Organizational effectiveness as compared to their male counterparts. These results partially support the first hypothesis of the study stating that there will be significant gender difference on the perception of all the dimensions of OrganizationalEffectiveness.

These results are supported by the findings of Bibi (2016) who reported gender biases in work setting because of that firms are not able to fully utilize major portion of women's talent pool. As we know that proactivity involves acting in advance of a future situation rather than just adjusting to a situation or waiting for something to happen. According to Grant \& Ashford (2008), Proactivity behavior involves activity in advance of future situation rather than just reacting. Proactive employees generally don't need to be asked to act nor do they require detailed instructions. So, proactivity is about initiating changes. Proactivity was found to report more among female 
executives. This may be attributed to the fact that females probably are more sincere and dedicated towards their work so they give their best to promote their companies and also try to excel in every field. So they don't need any external push to perform the task given to them. They are internally motivated to excel in their work. Hence they perceive more proactivity in the organizational effectiveness. Further Belongings was also perceived more by female executives as compared to males i.e. females involve themselves more in their job as compared to males.

No other dimensions of Organizational- Effectiveness was found to be significant across gender. The reason may be that nowadays workplace are changing, they are trying to remove gender biases for the sake of success of their business and to utilize the talent of both the male and females employees the best.

\section{Organizational-Effectiveness across Job-Types (Government \& Private):-}

As it is clear from the inspection of Table-2 that government and private executives differed significantly from each other only on few dimensions of Organizational effectiveness.It is clear from theinspection of Table-1 that private executives were found to perceive more Advancement- Opportunity and Task- Significance in the organizational effectiveness as compared to Government executives. These results partially accept the second hypothesis of the study stating that Executives of Government and Private Sector will differ significantly on the perception of all the dimensions of Organizational- Effectiveness. Although, it is true that as compared to Government executives, the private sector employees have to work hard and under extreme pressure and stress to increase their output and greater productivity but similarly it is also true that private sector companies provide a lot of advancement opportunities to their employees if they achieve the targets given to them. This works as potive reinforcement for their employees but in government sector although the job security is more but promotional opportunities are restricted. Career advancement is one of the most important element for employees' satisfaction and motivation to work hard which is provided more in the private sector. Task-Significance was also found to be more among private sector executives. Task- Significance is a measure of impact that determines an extent to which an employee's measurable and identifiable task affects tasks of other employees within or outside their organization. It shows how a piece of employee work relates to other work piece that are either done or in progress. The reason may be attributed to the fact that private companies have to continuously fight and maintain their positions in the international market, therefore, the employees can't lose hope (Gupta \&Sawhney, 2010). They have to think positive in the direction to bring changes and work even better than the past for the upliftment of the companies which indirectly results in their upliftment as well.

The interaction of Job-type and Gender was not found to be significant on any of the dimensions of the Organizational Effectiveness.

\section{Conclusion:-}

On the basis of the above results it can be concluded that government and private executives perceive organizational effectiveness differently and some gender differences were also reported on some of the dimensions of the organizational effectiveness. Success of any industry require egalitarianism i.e. it should not discriminate its employees on the basis of their gender. It should use talents best so should avoid difficulties in the vertical growth of the females. The results of the present study may throw light on how companies should deal their male and female workers for the maximum growth of their company. Different sectors of the industries should also change their policies accordingly. The study is especially more relevant in Indian scenario because India is going through rapid changes and more and more foreign companies are coming in India for investment and to gain profit.

Table-1:- Mean and SD on all the dimensions of Organizational Effectiveness among Government and Private Executives.

\begin{tabular}{|c|c|c|c|c|c|c|}
\hline $\begin{array}{l}\text { Organizational } \\
\text { Effectiveness }\end{array}$ & $\begin{array}{l}\text { Gover } \\
\text { Mean }\end{array}$ & $\begin{array}{l}\text { Secutives } \\
\text { SD }\end{array}$ & $\begin{array}{l}\text { Private- } \\
\text { Mean }\end{array}$ & $\begin{array}{l}\text { Executives } \\
\text { SD }\end{array}$ & $\begin{array}{l}\text { Total } \\
\text { Mean }\end{array}$ & SD \\
\hline Communication & 40.21 & 15.07 & 44.22 & 17.21 & 42.22 & 16.14 \\
\hline Male & 37.81 & 14.83 & 40.32 & 15.20 & 39.06 & 15.01 \\
\hline Female & 38.23 & 14.87 & 42.27 & 16.20 & & \\
\hline \multicolumn{7}{|l|}{ Total } \\
\hline \multicolumn{7}{|c|}{ Advancement Opportunity } \\
\hline Male & 40.59 & 19.12 & 44.32 & 20.19 & 42.46 & 19.65 \\
\hline Female & 35.62 & 17.89 & 38.59 & 19.09 & 37.10 & 18.49 \\
\hline
\end{tabular}




\begin{tabular}{|c|c|c|c|c|c|c|}
\hline Total & 38.11 & 18.51 & 42.46 & 19.64 & & \\
\hline \multicolumn{7}{|c|}{ Proactivity } \\
\hline Male & 31.87 & 10.62 & 31.89 & 9.48 & 31.88 & 10.05 \\
\hline Female & 32.52 & 9.87 & 38.42 & 7.24 & 35.47 & 5.05 \\
\hline Total & 32.19 & 10.25 & 35.16 & 8.36 & & \\
\hline \multicolumn{7}{|l|}{ Belongings } \\
\hline Male & 19.82 & 8.17 & 17.81 & 6.89 & 18.81 & 7.53 \\
\hline Female & 20.13 & 7.07 & 29.12 & 7.12 & 24.62 & 7.09 \\
\hline Total & 19.97 & 7.62 & 23.46 & 7.00 & & \\
\hline \multicolumn{7}{|l|}{ Task-Significance } \\
\hline Male & 27.20 & 5.62 & 29.63 & 8.19 & 28.41 & 6.90 \\
\hline Female & 16.89 & 7.23 & 29.67 & 7.00 & 23.28 & 7.24 \\
\hline Total & 22.04 & 6.43 & 29.70 & 7.50 & 25.84 & 7.07 \\
\hline \multicolumn{7}{|l|}{ Goal-Orientation } \\
\hline Male & 22.36 & 5.62 & 25.17 & 5.64 & 23.76 & 5.35 \\
\hline Female & 20.63 & 7.23 & 20.87 & 6.12 & 20.75 & 6.56 \\
\hline Total & 22.04 & 6.04 & 23.02 & 5.88 & & \\
\hline \multicolumn{7}{|l|}{ Security } \\
\hline Male & 7.41 & 3.03 & 7.28 & 1.99 & 7.34 & 2.51 \\
\hline Female & 6.25 & 2.13 & 6.59 & 2.87 & 6.42 & 2.50 \\
\hline Total & 6.83 & 2.58 & 6.93 & 2.43 & & \\
\hline \multicolumn{7}{|l|}{ Total OE } \\
\hline Male & 178.37 & 35.46 & 175.64 & 36.11 & 177.00 & 35.78 \\
\hline Female & 169.85 & 37.22 & 174.29 & 30.76 & 172.07 & 33.99 \\
\hline Total & 174.11 & 36.34 & 174.96 & 33.43 & & \\
\hline
\end{tabular}

Table-2:- F-ratios on different dimensions of Organizational effectiveness:

\begin{tabular}{|l|l|l|l|}
\hline $\begin{array}{l}\text { Organizational } \\
\text { fffectiveness }\end{array}$ & Main effect of Job Type & Main Effect of Gender & JTx G \\
\hline Communication & 1.53 & 0.43 & 0.32 \\
\hline Advancement opportunity & $4.23^{* *}$ & 1.51 & 0.24 \\
\hline Proactivity & 1.59 & $14.59^{* *}$ & 0.93 \\
\hline Belongings & 0.72 & $6.29^{* *}$ & 0.85 \\
\hline Task- Significance & $4.23^{* *}$ & 0.39 & 0.95 \\
\hline Goal-Orientation & 0.63 & 0.12 & 0.87 \\
\hline Security & 0.23 & 0.25 & 0.19 \\
\hline Total OE & 0.89 & $7.13^{* *}$ & 0.59 \\
\hline
\end{tabular}

$* *=$ Significant at .01 level

\section{Reference:-}

1. Bibi, N. (2016). Role of Gender Diversity in Organizational- Effectiveness and Its implications. International Review of Management and Marketing, 6 (S4) 80-85.

2. Dhar, S. \&Dhar, U. (2012). Organizational- Effectiveness Scale. National Psychological Corporation. KachehriGhat, Agra.

3. Grant, A. \& Ashford, S. (2008). The dynamics of proactivity at work. Research in Organizational Behavior. 28, 3-34 doi:10.1016/j.riob.2008.04.002

4. Gupta, N. \&Sawhney, E. (2010). Occupational Self- Efficacy: A Comparative study of Government and Private Sector Executives. Research, Analysis and Evaluation. Vol. I, Issue-9, 19-22

5. Richard et al (2009). Measuring Organizational performance. Towards methodological best practice. Journal of Management 4 (2).

6. Six Sigma (2017). What is organizational effectiveness, June. https://www.6sigma.us 